\title{
Communication
}

[Comunicação]

\section{Phylogeny of canine coronavirus (CCoV) from Brazilian dogs based on membrane protein partial sequences}

\author{
[Filogenia de Coronavírus canino (CCoV) de cães brasileiros com base em sequências parciais \\ da proteína de membrana]
}

\author{
M.P. Guirao, S.P. Souza, J.A. Jerez, L.J. Richtzenhain, P.E. Brandão*
}

Faculdade de Medicina Veterinária e Zootecnia - Universidade de São Paulo- São Paulo, SP

Enteric canine coronavirosis, caused by canine coronavirus $(\mathrm{CCoV})$, is an endemic infectious disease with worldwide distribution and high morbidity in puppies, with Types I and II CCoV described so far (Pratelli et al., 2004).

$\mathrm{CCoV}$ is a member of the genus Alphacoronavirus, family Coronaviridae, Order Nidovirales, with a single-stranded, positivesense linear non-segmented RNA with $27 \mathrm{~kb}$ and a helical nucleocapsid formed by the nucleocapsid N protein (Masters, 2006).

The viral envelope contains the membrane (M), spike (S) and envelope (E) proteins, resulting in a virion of about $220 \mathrm{~nm}$ in diameter (Holmes and Lai, 1996; Masters, 2006).

Recently, a pantropic variant of $\mathrm{CCoV}$ was described which replicates in the lungs, kidneys, liver, spleen and lymph nodes leading to epidemics and high mortality in puppies (Buonavoglia et al., 2006).

Although described as a worldwide distributed virus, there are no reports on molecular data of Brazilian strains of $\mathrm{CCoV}$.

This article reports the preliminary results of a survey on the occurrence of $\mathrm{CCOV}$ in Brazilian young dogs and the distribution of Types I and II of the virus based on partial sequencing of the membrane protein gene.

Recebido em 4 de fevereiro de 2013

Aceito em 1 de agosto de 2013

* Autor para correspondência (corresponding author)

E-mail: paulo7926@usp.br
Twenty-two fecal samples were collected from dogs with ages ranging from 1 to 6 months, all of them non-vaccinated against $\mathrm{CCoV}$. Sampling was by convenience, without statistical methods, and the presence or absence of diarrhea was not taken into account at that moment.

The samples were collected at kennels located in Sao Paulo State, Southeastern Brazil, including Sao Paulo and other four bordering cities, in 2007 and 2008, and were prepared as $20 \%$ suspensions (v/v) in ultra-pure water treated with $0.1 \%$ diethyl-pyrocarbonate and clarified at $5,000 \mathrm{~g} / 15$ minutes at $4^{\circ} \mathrm{C}$. Total RNA was extracted from the supernatants with TRIzol ${ }^{\mathrm{TM}}$ (Invitrogen, Carlsbad, USA) according to the manufacturer's instructions.

Partial membrane protein gene of $\mathrm{CCoV}$ was amplified with the RT-PCR and the primers CCV1 and CCV2 described by Pratelli et al. (1999) (410bp amplicon, nucleotides 337 to 746 of $M$ gene of Type II CCoV strain 1-71 GenBank Accession number AY704916.1), using M-MLV Reverse Transcriptase ${ }^{\mathrm{TM}}$ and Platinum Taq DNA Polymerase $^{\mathrm{TM}}$ (Invitrogen, Carlsbad, USA), according to the manufacturer's instructions.

The positive control was the vaccine Recombitek $^{\mathrm{TM}}$ (Merial Animal Health, Brazil) and the negative control was DEPC-treated water. Exclusive rooms were used for sample preparation and RNA extraction, reverse transcription and amplification reactions as well as for electrophoresis in order to avoid amplicon carry-over. 
The amplicons were directly purified from PCR reactions with Ilustra ${ }^{\mathrm{TM}}$ GFX PCR DNA and Gel Band Purification (GE Healthcare, Buckinghamshire, UK) and submitted to bidirectional cycle sequencing using BigDye $3.1^{\mathrm{TM}}$ (Applied Biosystems, Carlsbad, CA, USA), according to manufacturer's instructions. The sequences were resolved in an ABI-377 Automatic Sequencer (Applied Biosystems, Carlsbad, CA, USA).

Sequences were assembled with Cap-Contig in Bioedit v.7.0.5. (Hall, 1999) using only chromatograms positions showing Phred score
$>20$ after analysis at http://asparagin.cenargen. embrapa.br/phph/.

A distance neighbor-joining tree with the Poisson correction was built for the putative amino acids sequences aligned with the BLOSUM 62 matrix and the CLUSTAL/W algorithm in Bioedit v.7.0.5. (Hall, 1999), with CCoV types I and II sequences retrieved from the Genbank (Accession numbers in Figure 1) and $\mathrm{BCoV}$ (Accession number NC003045) as an outgroup using Mega 4 (Tamura et al., 2007) with 1,000 bootstrap replicates.

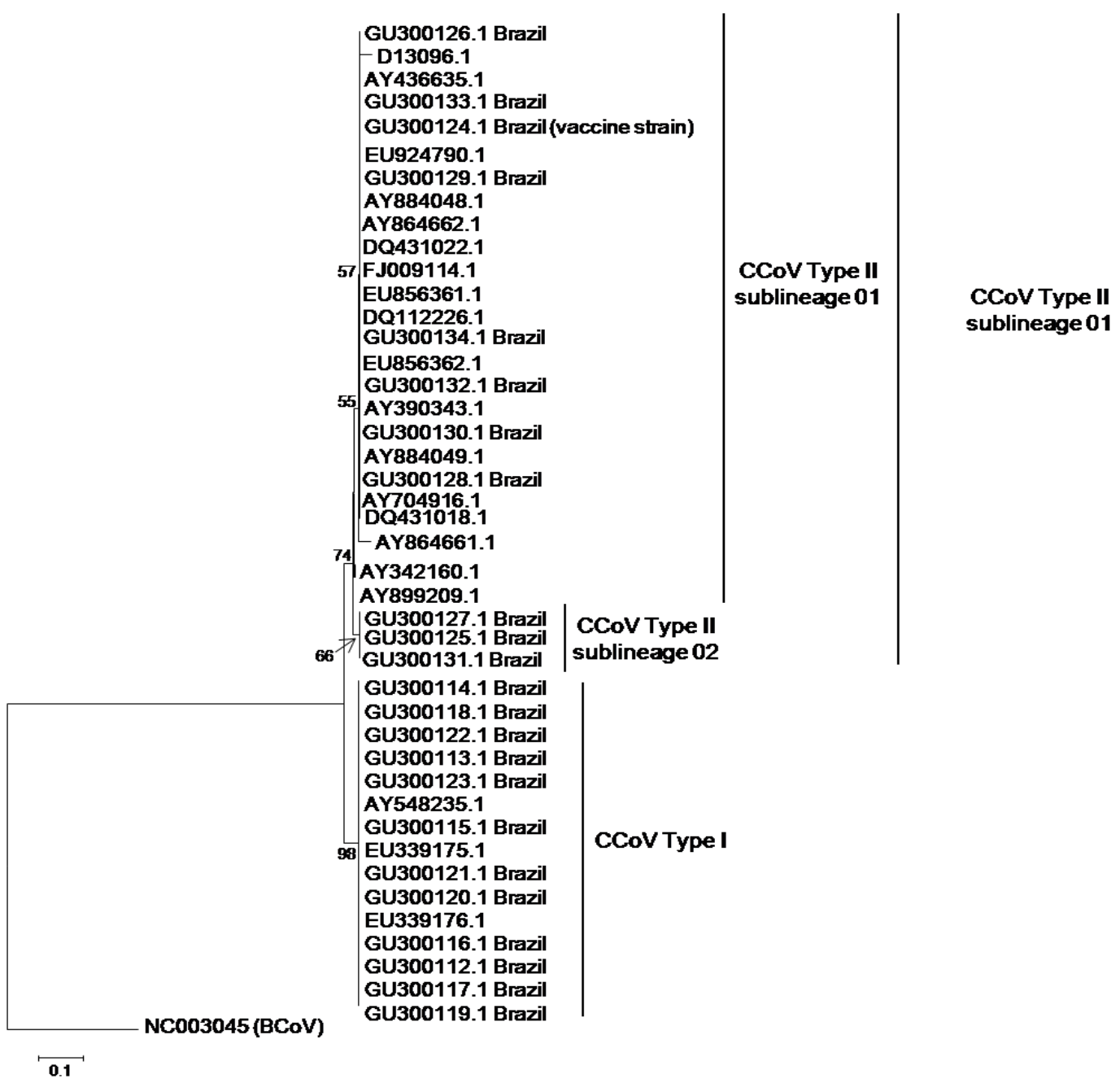

Figure 1. Rooted neighbor-joining amino acids distance tree with the Poisson correction for the residues 156 to 229 of Canine coronavirus $(\mathrm{CCoV})$ membrane $\mathrm{M}$ protein showing the strains from the present study (Genbank Accession number followed by Brazil) and sequences retrieved from the Genbank and the clusters Type II with sub-lineages 1 and 2 and Type I. Numbers at each node are 1,000 bootstrap replicate values. The bar represents the number of substitutions per site. 
The sequences obtained for the $23 \mathrm{CCoV}$ strains (vaccine strain included) have been assigned Genbank accession numbers GU300112 to GU300134.

Ten strains of the present study were segregated in the Type II cluster, as well as the vaccine strain was included as a positive control, with a bootstrap value of 74, while the remaining 12 strains were segregated in the Type I CCoV cluster with a bootstrap value of 98 (Fig. 1).

Regarding the Type II cluster, it can be noticed in Fig. 1 that the three Brazilian strains formed a sub-cluster, named as Type II sub-lineage 02, but only supported by a bootstrap value as low as 66, while the other strains were grouped in the subcluster named Type II sub-lineage 01 .

Intra-cluster amino acid identities for Type I, Type II sub-lineage 01 and Type II sub-lineage 02 were $100 \%$. The mean amino acids identities amongst the vaccine strain and these clusters were $100 \%$ for Type II sub-lineage $01,97.2 \%$ for Type II sub-lineage 02 and $93.2 \%$ for Type I.

Mean amino acids identities between Type II sub-lineages 01 and 02 were $98.6 \%$ and 94.5 and $93.2 \%$ between these and Type I, respectively.

No mixed CCoV Types I and II and no geographic or chronological clustering in found amongst the 22 studied strains, what might mean that the $\mathrm{CCoV}$ detected lineages are continually perpetuated in Brazilian dogs.

The occurrence of Types I and II CCoV was a previously unknown fact in the Brazilian territory.
In a similar survey carried out in Sweden, a sublineage of Type II CCoV was also found (Escutenaire et al., 2007), regarding exactly the same $M$ gene region analyzed herein and the $S$ gene; besides, a similar finding was described in Australia (Naylor et al., 2001), showing that the emergence of sub-lineages for Type II CCoV is a common evolutionary event.

Although Types I and II co-infection were not detected in the present study, this must be interpreted with caution as such information could only be confirmed or discarded by the use of type-specific conventional or real-time PCRs (Pratelli et al., 2004; Decaro et al., 2009) or by cloning the amplicons prior to DNA sequencing, a matter for future studies with the samples described herein.

$\mathrm{CCoV} \mathrm{M}$ protein is highly immunogenic in the amino terminal Escutenaire et al. (2007) but more accurate inferences should take into account other and larger areas of $\mathrm{CCoV}$ genome, primarily the spike protein, the main target for neutralizing antibodies in coronaviruses (Masters, 2006), prior to any statements about Brazilian sub-lineages.

As a conclusion, this study demonstrates that both Types I and II CCoV occur in Brazil, and a supposed Brazilian sub-lineage in Type II will be investigated in further detail by sequencing of other parts of the genome.

Keywords: coronavirus, dogs, phylogeny, membrane, Brazil

\section{RESUMO}

Este artigo descreve a anteriormente desconhecida diversidade molecular de amostras brasileiras de Coronavírus canino (CCoV). Vinte e duas amostras foram submetidas à análise da sequência parcial do gene codificador da proteína de membrana, sendo 12 classificadas como CCoV Tipo II e 10 como CCoV Tipo I e uma possível sublinhagem tipicamente brasileira foi encontrada para o CCoV Tipo II.

Palavras-chave: coronavírus, cães, filogenia, membrana, Brasil 


\section{ACKNOWLEDGEMENTS}

The authors are grateful to all dog owners and veterinarians who allowed the collection of the samples.

\section{REFERENCES}

BUONAVOGLIA, C.; DECARO, N.; MARTELLA, V. et al. Canine coronavirus highly pathogenic for dogs. Emerging Infect. Dis., v.12, p.492-494, 2006.

DECARO, N.; DESARIO, C.; BILLI, M. et al. Western European epidemiological survey for parvovirus and coronavirus infections in dogs. Vet. Journal, v.187, p.195-199, 2011.

ESCUTENAIRE, S.; ISAKSSON, M.; RENSTRÖM, L.H. et al. Characterization of divergent and atypical canine coronaviruses from Sweden. Arch. Virol., v.152, p.1507-1514, 2007.

HALL, T.A. BioEdit: a user-friendly biological sequence alignment editor and analysis program for Windows 95/98/NT. Nucleic Acids Symp. Ser., v.41, p.95-98, 1999.
HOLMES, K.V.; LAI, M.M.C. Coronaviridae: the viruses and their replication. In: FIELDS, B.N.; KNIPE, D.M.; HOWLEY, P.M. (Eds.) Virology. Philadelphia: Lippincott-Raven Publishers, 1996. p.1075-1093.

MASTERS, P.S. The molecular biology of coronaviruses. Adv. Virus Res., v.66, p.193-292, 2006.

NAYLOR, M.J.; HARRISON, G.A.; MONCKTON, R.P. et al. Identification of canine coronavirus strains from feces by $\mathrm{S}$ gene nested PCR and molecular characterization of a new Australian isolate. J. Clin. Microbiol., v.39, p.1036-1041, 2001.

PRATELLI, A.; DECARO, N.; TINELLI, A. et al. Two genotypes of canine coronavirus simultaneously detected in the fecal samples of dogs with diarrhea. J. Clin. Microbiol., v.42, p.1797-1799, 2004.

PRATELLI , A.; TEMPESTA, M.; GRECO, G. et al. Development of a nested PCR assay for the detection of canine coronavirus. J. Virol. Methods, v.80, p.11-15, 1999.

TAMURA, K.; DUDLEY, J.; NEI, M. et al. MEGA4: molecular evolutionary genetics analysis (MEGA) software version 4.0. Mol. Biol. Evol., v.24, p.15961599, 2007.

YESILBAG, K.; YILMAZ, Z.; TORUN, S. et al. Canine coronavirus infection in Turkish dog population. J. Vet. Med. B Infect. Dis. Vet. Public Health, v.51, p.353-355, 2004. 